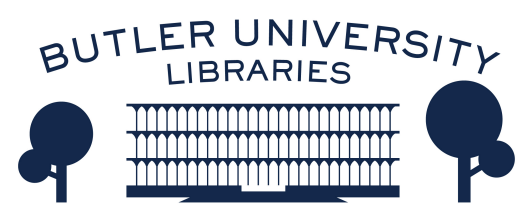

Journal of Hindu-Christian Studies

Volume 18

Article 16

January 2005

\title{
Book Review: "In Search of Identity: Debates on Religious Conversion in India"
}

Corinne Dempsey

Follow this and additional works at: https://digitalcommons.butler.edu/jhcs

Part of the Religion Commons

\section{Recommended Citation}

Dempsey, Corinne (2005) "Book Review: "In Search of Identity: Debates on Religious Conversion in India"," Journal of Hindu-Christian Studies: Vol. 18, Article 16.

Available at: https://doi.org/10.7825/2164-6279.1349

The Journal of Hindu-Christian Studies is a publication of the Society for Hindu-Christian Studies. The digital version is made available by Digital Commons @ Butler University. For questions about the Journal or the Society, please contact cbauman@butler.edu. For more information about Digital Commons @ Butler University, please contact digitalscholarship@butler.edu. 
and Astanga Yoga. In contrast, "Modern Meditational Yoga" puts more stress on mental practices such as is seen in early TM, Sri Chinmoy and some modern Buddhist groups. A chart outlining this typology is offered on p.188 and will be very helpful for teaching purposes. A separate offshoot is called "Modern Denominational Yoga" by the author. It is characterized by a focus on Neo-gurus and on the school's own teachings which are given authoritative status. Examples include the Brahma Kumaris, Sahaja Yoga, ISKCON, and late TM. After establishing her typology of Modern Yoga groups, the author identifies three developmental phases: popularization (1950s to mid-1970s), consolidation (mid1970 s to late 1980s) and acculturation (late 1980 s to the present). These phases are described and discussed mainly with reference to the longer established Postural Yoga schools in the UK. There has been an increase of those practicing postural yoga of about 300 percent from 1970 to 1993 when those attending classes in Britain are numbered at 120,000 and its popularity continues to grow.

The last fifty pages of the book present a case study of one such school, namely the Iyengar School of Modern Postural Yogas, which it is claimed is the most influential and widespread of all the postural schools. The author successfully employs her own typology (described above) to analyze the theory and practice of the Iyengar School of Modern Yoga.

This carefully researched and well written book fills in an important gap in knowledge - how we got from the classical school based on Patanjali's Yoga Sutras to the modern forms of yoga that we encounter in community recreation centers, college adult education programs and in popular books. As a scholar who has carefully studied Patanjali's Yoga Sutras (with my teacher, T.R.V. Murti) and published on them (e.g., Yoga and Psychology (SUNY Press, 2002), I have always been puzzled by the modern practitioners who often cite the Yoga Sutras but are so different. Thanks to this book, I, and my students, have a much better understanding and a sound basis for further study:

Harold Coward University of Victoria

\section{In Search of Identity: Debates on Religious Conversion in India. Sebastian C.H. Kim. New Delhi: Oxford University Press, 2003, 250pp.}

\begin{abstract}
IN Search of Identity is a meticulously researched, clearly written walk through the many-angled history of conversion debates in India. The book offers a rather straightforward overview of Hindu-Christian exchanges from the early nineteenth century to date yet, unlike many other writings in the field, focuses on debate and discordance rather than dialogue. Also distinguishing $\mathrm{Kim}$ is his interest in exploring the problem of conversion on theological rather than practical grounds. His book, as he puts it, aims not so much at exploring why people change their religion but rather why
\end{abstract}

conversion has historically, been so problematic. Although the answer is undeniably tied to shifting and conflicting socio-economic, cultural, and political realities, Kim believes the issue cannot be resolved without considering pertinent theological differences between Hindu and Christian traditions. Kim argues that the inter-religious dispute over conversion in India repeatedly reaches an impasse due to failure on both sides to effectively hear the theological and ideological underpinnings of the other's argument. In Search of Identity is an attempt to challenge this impasse by 
offering voice to the ideological complexities of both sides of the debate, providing an opportunity for listening and for understanding.

The book begins with inter-religious debates conducted under the British Raj and highlights various discussions during the early nineteenth century as well as several of Gandhi's exchanges roughly a century later. While the tenor of these debates varies depending on circumstances and conversation partners, several themes emerge that not only delineate key differences between religious views, but lay a foundation for subsequent disputes. One theme is the evangelical Christian assumption that radical change (conversion) is necessary for spiritual discovery versus a Hindu privileging of dharma or duty to one's community and nation. One of Gandhi's concerns, relevant in particular to mass conversion, is that conversion not only impedes one's adherence to dharma but also undercuts a genuine relationship between divinity and humanity that is meant to be personal, not public. Probably the most insistent discontinuity between Hindu and Christian ideologies has been the Christian stance that conversion and proselytization are human rights to be protected contrasted with the Hindu view that holds religious tolerance as a defining principle.

Kim then discusses the ways in which conversion debates have woven their way into the government documents. While the phrase "right to proselytize" was begrudgingly approved into the Constitution, the Niyogi Report of the 1950s sharp critiqued missionary aims and goals and recommended that Christian groups conducting conversions be banished from India. Kim deftly outlines the arguments rallied between the Hindu and Chrisitian communities in the wake of the Report, noting how both sides seemed equally intolerant and unable to respect the rights of the other. Chapters five and six switch gears by discussing subsequent Protestant and Catholic theologies - developed both in India and worldwide - that aim at crafting new meanings and practices of conversion.
These attempts to hammer out fresh positions are partially in response to the criticisms of the Niyogi Report as well as worldwide discussions about the gospel imperative to promote humanization and justice.

Protestant debates during the 1960 s and 1970s, highlighted in chapter five, overwhelmingly repudiated forced or coerced conversion yet disagreed over the proposition - developed primarily by M.M. Thomas and Kaj Baago - that Hindus and Christians alike were called not to separate communities but to a common, Christcentered, secular. fellowship. Kim, along with other theologians, finds this position unrealistic and particularly problematic for dalit converts. Since dalits do not typically identify with Hinduism to begin with, denying them a sense of community would be to deny them the religious identity they finally gained through Christianity. On the Catholic front, conversion debates during the $1980 \mathrm{~s}$ spawned inculturation and liberation approaches that, Kim notes, are often at cross purposes. Inculturationists who integrate Sanskritic practices into liturgy accuse liberationists of being insensitive to Hindu traditions; the latter accuse the former of elitism and insensitivity to caste inequity. Kim finishes this section on intra-religious debate by noting how the 1990s brought a synthesis of inculturation and liberation approaches in which Hinduism and Christianity are presented as equally legitimate vessels for encountering the Ultimate. Rather than winding down the conversion debate, Kim reminds us that the secular fellowship Protestant approach as well as the synthesizing/liberation Catholic approach in some ways contributed to a resurgence of evangelical Christian efforts at promoting radical spiritual conversion.

On that note, chapters six and seven once again move us to different terrain, to "Mission India 2000," launched in 1992 by evangelical Protestants, and "Evangelization 2000," launched primarily by Charismatic Catholics in 1987. These movements, widely criticized by Indian theologians, did not go unnoticed by Hindus. Inflaming anti- 
conversion views and verifying Hindutva suspicions that Christianity and imperialism are inextricable, evangelization 2000 efforts were countered by Hindu shuddhi reconversion ceremonies. Kim presents the writings of Arun Shourie as thoughtfully representative of Hindu nationalist views and notes that although he may have unfairly criticized diversity within Christianity as a sign of weakness - in comparison with Hinduism he contrived as united - Shourie offered an opportunity for honest debate that Christians missed. Not only did they bypass a chance to learn from an esteemed journalist, they failed to convince Shourie and others of Christianity's new humility. Without acknowledging Shourie's theological reservations, Christians responded to the connections he drew between Christianity and imperialism. Attempting to deny links between Christianity and empire, respondents disingenuously drove a false wedge between the past and present.

Kim's discussion of the debate initiated by Sangh Parivar in the 1990s chronicles a more dramatic and ironic. crossfire of blame between and among religious communities. The Parivar's critique of Christianity as intolerant emerged amid their own acts of anti-Christian violence, their rejection of Christianity's universalism amid a campaign for an allIndia Hindutva. Mainline Catholic and Protestant embarrassment regarding evangelical Christian ideology led them to label evangelical groups "fringe" yet such dismissals were unconvincing. Even among mainline denominations, poor parishioners often feel differently about conversion than their middle class pastors; official Vatican statements such as Ecclesia in Asia promote a view of conversion very different from that of its progressive theologians.

Kim's book captures well the complexity of conversion debates from an impressive array of angles. Most impressive, however, is how he manages to remain terrifically even-handed in his treatment of what is often an emotional minefield. He concludes his book by proposing a Christian theology of conversion developed through open scrutiny by non-Christians. He suggests Christians assess the entanglement of foreign missionaries as well as the processes of colonialism, post-colonialism, and globalization yet take into account converts' testimonies of transformation. While both Hindus and Christians must consider the limitations of tolerance within their respective traditions, Kim asks that Christians work from the Golden Rule, offering the same respect for Hindu faith and identity that they would wish in return. In other words, Christian evangelism would be justified only to the extent that Christians would be willing to listen to and learn from Hindus.

Corinne Dempsey

University of Wisconsin at Stevens Point

\section{Playing Host to Deity: Festival Religion in the South Indian Tradition. Paul Younger. New York: Oxford University Press, 2002, vi +189 pp.}

IT never occurred to me that, given a chance, South Indian festivals had so many stories to tell. It does not surprise me, however, that Paul Younger, consummate yarn spinner with decades of experience chronicling South Indian history and ethnography, would be the one to give voice to these multi-registered events. In Playing Host to Deity, Younger deftly guides the reader through the variegated histories, mythologies, political vagaries, and practices of fourteen south Indian religious 